\title{
HEALTH COMMUNICATION MESSAGE PLANNING IN INSTAGRAM
}

\author{
Febri Santa Nova, Isbandi Sutrisno, Kurnia Arofah \\ Department of Communication Science \\ Faculty of Social and Political Sciences, UPN "Veteran" Yogyakarta \\ Email: febrynovha@gmail.com
}

\begin{abstract}
Health communication is interpersonal communication focused on how an individual faces health-related issues and seeks to maintain his health. The lack of awareness and public knowledge about oral health is why many clinics and illegal noneducated dental practicians in Indonesia nowadays. The emergence of an Instagram account @ korbantukanggigi is one way to make the public aware and educate the public about the dangers and consequences of illegal noneducated dental practician. This research aims to determine the process of message planning on the @ korbantukanggigi Instagram account about unlawful noneducated dental practicians' education. This research using the Planning Theory by Charles Berger and New Media Theory. The method used is descriptive qualitative research, collecting data through indepth interviews, observation, and documentation. The research results in planning messages there were five stages: the report stage, discussion stage, the drafting of the statement, goals, and the success of delivering the message. In implementing the message production technique, the researchers found that the @ korbantukanggigi account used the humorous appeal technique and the one-side issue in providing education. Korbantukanggigi has created opportunities for new knowledge about a dentist's world, a place to share the viewpoint of the illegal noneducated dental practician and education related to dental and oral health, which the public largely ignored.
\end{abstract}

Keywords: Dental Health Education, Planning, Instagram, Korbantukanggigi

\section{INTRODUCTION}

Communication is an essential activity in human life. It is created to meet all the needs that exist and is necessary. A human can determine various things such as expressing opinions and problems, solving problems, informing, and entertainment, informing knowledge and news and instilling thoughts and beliefs from communication. Likewise, in the case of health, communication can be a tool to support health improvement. The critical role of health communication has also been mentioned in the Healthy People 2010 Final Review (CDC, 2019), which states "use communication strategically to improve health." One kind of strategic communication is using new media. New media is experiencing rapid growth. Instagram is one of those social media where the number of users is increasing significantly. Through the Instagram phenomenon, this can be used by various people or groups to form a new network of friends. They created to develop communities based on shared hobbies, 
making groups, and other virtual activities. One of them is the emergence of an Instagram account based on health education@korbantukanggigi or commonly shortened as Kortugi. Kortugi is an educational account of the actions of illegal noneducated dental practician who practice unlawful and dangerous. Kortugi has started posting since August 2016, precisely on the 11th with the title File \# kortugi0001. Since their first post, Kortugi has committed to sharing posts related to illegal practices carried out by unlawful noneducated dental practicians.

Based on the 2018 Riskesdas results presented by the Ministry of Health, the average proportion of dental and oral problems was $57.6 \%$. The number was getting services from dental, medical personnel by $10.2 \%$. For the Special Region of Yogyakarta itself, the proportion of dental and mouth problems is $70 \%$, with the handling of medical personnel by $17 \%$. The balance of teeth brushing behavior correctly (brushing teeth twice a day, morning and night) in the population aged over three years in Indonesia recorded an average of $2.8 \%$ and in the Special Region of Yogyakarta recorded 6\% (RI, 2018).

Health education is crucial. It is created to know the importance of oral and dental health and the risks if people underestimate quality and competence. They are influenced by the low prices that illegal noneducated dental usually offers. According to the history of illegal noneducated dental practicians, it was the ancestor to intellectual dentists' existence and then developed after higher education became dentists. In the public's eyes, many people are equalizing the illegal noneducated dental practicians with dentists.

In giving education, Korbantukanggigi accounts use an easy and straightforward way, specifically by using captions or posting messages that are interesting to be read by followers. According to Cassandra, managing messages in Kortugi was analyzed with message management techniques in the book Cangara which is divided into three, such as informative messages, persuasive, messages and based on the side message (Cangara, 2007).

This phenomenon is related to the two theories. The first theory from Charles Berger is Planning Theory, which explains how individuals plan their communication behavior. Berger writes that plans for communication behavior are "hierarchical cognitive representations of goal-directed action sequences." In other words, visions are mental images of the steps one will go through to meet a goal. Planning, then, is the process of thinking up these action plans (Littlejohn \& Foss, 2011). Berger's theory predicts that the more you know (specific 
and general), the more complex your project will be.

Second is the theory of new media; it is associated with the chosen social media as a tool to educate with two dominant views in this theory. In the first media age, with its emphasis on broadcast, and the second, its focus on networks. These are the social interaction approach (social interaction) and the social integration approach (social integration). The social interaction approach distinguishes media in terms of how close they come to the model of face-to-face interaction. Older forms of broadcast-oriented media emphasize the transmission of information, which reduces the possibility of exchange.

In contrast, new media are more interactive and create a new sense of personalized communication (Littlejohn \& Foss, 2011). In recent social media, virtual meeting places expand social worlds, create new possibilities for knowledge, and share perspectives worldwide. The second way in which media are distinguished is in terms of social integration. This approach characterizes media not in terms of information, interactions, or dissemination, but in terms of ritual, or how people use media to create community.

\section{METHOD}

This type of research used in this research is descriptive qualitative research.
Determination of the subjects or informants in this study was using purposive sampling to determine samples based on several criteria. In this study, data collection techniques used observation, documentation, and in-depth interviews with several informants, including two informants who role as admin of the @ korbantukanggigi account, two dentists, and several followers of the $@$ korbantukanggigi account. To check the validity of the data, the researcher used the triangulation source.

\section{DISCUSSION}

The presence of new media makes society free to access and use it, including the new Instagram media. Because of observing the great opportunities in this field and the low awareness of the society, many of these peoples took the chance to make more the illegal noneducated dental practice fields labeled with beauty clinics. It is not even surprising if "they" try to sell their businesses by convincing customers better than what dentists can do in general. Promising and convincing with low prices and showing the results before and after the aroused interest. Even the pictures they promised can be edited and taken from the dental accounts.

The government that has to manage illegal noneducated dental practicians in Indonesia has not fulfilled its job well. It 
can be seen from the people who do not know the fundamental difference between illegal dental practicians and a dentist's duties.

In analyzing the planning of message production, the researcher used the theory of Planning by Charles Berger and the concept of message management techniques. Message planning carried out by the@korbantukanggigi Instagram account can be described in five stages, namely :

The report stage is the primary stage in message planning in Kortugi because, in this stage, that Kortugi has a discussion that can be uploaded on Instagram. This stage gets a lot of cooperation, such as reports from the public, dental partners, and victims from the illegal noneducated dental practician himself. In this stage, the sorting of cases. Sorting is done with two specific criteria. These particular criteria are; (1) All Kortugi uploads must have education in the message, and (2) Kortugi uploads are based on the topic of education, not based on the case.

The second stage to designing messages in Kortugi is forum because the incoming cases will be discussed by the admin member of Kortugi, which consists of general dentists and specialists through the Whatsapp online application to create what message should be used for the case. In this stage, doctors are allowed to express their opinions, then considered a topic that will be selected as uploads.

Creating a message is when captions and editing of images are done, or a message packaging was done. Message packaging itself is a message engineering where the ideas will be reproduced by the communicator (admin), packaged, and then sent back for communication with other people (followers). In creating a caption, the technique used is three-technique, often used by comics and sometimes drg. Rifqie only uses two stages in the rule of three, which is set up and punchline. The image used and uploaded in the @korbantukanggigi account is the result of editing done by drg. Rifqie himself as the main admin.

The goal stage is the results to be reached from the two previous steps. The purpose of Kortugi itself is to educate the society about the dangers of illegal noneducated dental practician. In other words, the earlier stages are planning to achieve these goals.

The success stage of delivering a message is when the communicator (Kortugi) can see the communicant's responses regarding the subject matter. The communicants will respond according to their understanding of the subject matter given. From this, the communicator can assess whether the delivery of the message delivered was successful or not. 
Another step in message planning is the management of messages. Cassandra, based on Cangara's book, Introduction to Communication Studies, uses three techniques in managing messages, namely informative messages, persuasive messages, and messages based on the displayed sides. Kortugi has practiced the application of these three message management techniques. Informative messages are divided into four, namely space order, time order, deductive order, and inductive order.

1. Space order, messaging that looks at the conditions of a place or space, such as international, national, and regional.

Text: "From Handil, Muara Jawa, East Kalimantan, here's the experience: The dentures cost 500 thousand. Initially, it was not agreed. But the artisan's persuasion allowed him to be paid a week later"

Messaging with space orders is evidenced by place names like using specific areas such as Muara Jawa, East Kalimantan. It is to inform followers of the site where the case happened.

2. Time order, the arrangement of messages based on time or period.

Text: "... Initially, the dentures were installed as usual. A week later, he (the patient) complained of bad breath and bad shape. The condition made him have to return to the dentist. The solution is to cover up the ugliness, decorate it with stirrups ..."
Messaging with a time order is proven by a time sequence as first and a week later. It is to inform followers chronologically about a time when the case occurs and also to give a warning that in any case, there will be an effect later, both in the short or long term.

3. Deductive order, messaging from general to specific.

Text: “... 45-year-old men with complaints of bad breath and loose teeth all came to the dentist @ yogi.s.a. The upper jaw has a splint attached. The lower jaw is fitted with a 3-month denture attached with the other teeth that cannot be removed. Shaky too ..."

In the example, it is explained that the victim of the and illegal noneducated dental practician is conscious of the condition after feeling his teeth shake. The explanation becomes general about the state of the man. Then things that are more specifically explained about what happened to the teeth.

4. Inductive order, messaging from particular to general.

Narasi: “... (specifically) there are two kinds of acrylic for dentures: heat curing and self-curing..."

"... (General) This is why the acrylic denture that should be designed to be easily padded becomes permanent..."

In the case above, the message order can be categorized as an inductive order from an explanation of what acrylic is for specific dentures and explains in general why 
acrylic dentures should not be permanently placed on teeth.

Composing a persuasive message is more towards how this message can change people's perceptions, attitudes, and opinions about health. A compelling message is divided into five, according to Cassandra, namely:

1. Messages that use threats in the message create fear

Text: "... Infection from the root of the maxillary teeth causes an accumulation of pus in the cheek area which then looks for a way out. ..."

“... For example, the case of dentures made by dental artisans, which triggers oral cancer. Oral squamous cell carcinoma (SCC) is cancer that most often becomes the final diagnosis by dentists who specialize in oral diseases ..."

A message with fear appeal techniques such as the example above, explaining the consequences of not doing the right treatment and the handling needed. In the two examples above, explaining the effects of tooth root infection resulting in cavities and presenting dentures that cause oral cancer is a threat if the disease is not treated immediately. This fear order received many responses from the followers. In the upload, the fear appeal is in composing messages and visuals of uploads about the illegal dental practitioners victims' condition. This fear order received many responses from the followers. The fear appeal composes messages and visuals of uploads about the illegal dental practitioners victims' condition in the upload.

2. Messages with an emotional appeal that can evoke emotions

Text: "... It's like putting an 'implant'. At least we can use two years. You can't imagine being exposed to tetanus or other infectious diseases. Good thing, the right person is now handling this poor mother. A dentist who specializes in dentures. His practice place is more than $433 \mathrm{~km}$ from where he lives. How difficult is it to access dental health services in Aceh? FKG students from Aceh quickly graduated. The people there need you "

The emotional appeal message on the upload was created by describing the problem felt by an Aceh who had to travel a long distance to get medical treatment.

3. Reward appeal is messaged by giving promises to the public.

Researchers have not found this kind of message appeal in uploads @korbantukanggigi. It is reasonable by the existence of ethics in dentistry where dentists are not permitted to make promises to the public.

4. The motivational attraction is the arrangement of messages that motivate the audience.

Text: “Inspirational Dentist's Story: dentist Maruli Juara Aritonang (@aritonangmaruli). Dentist Maruli opened a clinic on Jalan Viyata Yudha, Siantar Sitalasari District, 
Pematangsiantar City, since 2014. Free for patients with disabilities..."

Above is an example of messaging with the motivational appeal on the @korbantukanggigi account. The comments also made it clear that the cases above could be categorized in motivational appeal.

5. Humor appeal is a technique that uses humor in its message.

Text: “... Dental artisans no longer humanize humans. But materialistic. Compared to the customers, the kuntilanak is still more fortunate. Just pay attention to the nails so that when they are plugged in, they can immediately make a fussy kuntilanak get into a good mood...."

This technique is the most commonly found in the @korbantukanggigi account. Humor in@korbantukangigi is often found in the caption. This humor to attract followers to read captions that not only contain humor but are also educational.

There are also techniques for designing messages based on the side displayed. Divided into two according to Cassandra (Cangara, 2007). 1) one-sided issue, a statement that only shows one side, for example, only displays the goodness of the message topic and does not reveal its ugliness. 2) the two-sided issue displays a message from two sides at once from the good and bad sides. In the account @korbantukanggigi, researchers have not found any messaging with a two-sided issue in their uploads. Researchers think that these cases are just about the mistreatment of illegal dentists, so looking for posts that display positives cannot be justified.

"I am of the view that as a dentist, I agree with Kortugi's uploads. From a dentist's point of view, they are incompetent practitioners, illegal so it doesn't deserve to be brought up on the bright side. Besides, Kortugi also emphasized that it was about illegal practitioners, so that the one-sided was just right in my opinion. Another difference is that under the supervision of a dentist, a dental technician makes dentures according to their competence." (Dentist Yasmin, on interview 9 July 2019).

After making observations in Kortugi @korbantukanggigi's social media, researchers can analyze that the messages created by Kortugi are dominant order with the humorous appeal. Researchers assume, based on the results of interviews with drg. Rifqie, who said that all uploads in the @korbantukanggigi account were educational in an entertainment format.

The purpose of a persuasive message is to change people's perceptions, attitudes, and opinions about a matter. The purpose of this message is in line with the views expressed by Liliweri Alo (Liliweri, 2015). Health communication also has the primary goal of disseminating health information to achieve healthy living behaviors, creating awareness, changing attitudes, and motivating individuals to follow healthy behaviors that are recommended. In other words, the 
messages used by Kortugi are messages that are suitable for use in the field of health communication.

In a new media concept, there is an emphasis on social interaction and social integration. In the social interaction, it is said that it provides virtual meeting places that expand social worlds, create new possibilities for knowledge, and provide a sharing of perspectives worldwide. The Kortugi Instagram account has created new knowledge opportunities about the world of dentistry and a place to share broad views about the illegal noneducated dental practician and other education-related to oral health that is mostly ignored by the public. New media with social integration illustrates how humans use media to create societies that provide a sense of mutual ownership. When connected to the @korbantukanggigi account, Kortugi has now created a community aware of dental and oral health problems.

In its growth, Kortugi experienced a change of goal initially only as a dentist archive into a health education-based account. In planning theory, plans are a mental picture of the steps a person will take to fulfill a goal. Goals can also be arranged in a hierarchy of objectives where success in achieving the first goal makes it possible to carry out the second and subsequent goals. In this case, the case uploaded and intended as an archive is the first destination owned by @korbangtukanggigi. After a long journey where followers are increasingly diverse, supported by many parties, the second goal of Kortugi comes, namely as an educational account of illegal dental practices. The second goal will not be achieved if the first goal has not been reached.

\section{CONCLUSION}

Based on the results of the research and discussion above, the author finally concluded from research on Planning Health Communication Messages on Instagram in educating illegal noneducated dental practician as follows:

1. Oral health must be considered by the public. Social media can be used by everyone so that educational platforms like Kortugi must be further developed.

2. Kortugi has planned message production in five stages; Namely, the reporting stage when the case is presented. Second, the forum stage where cases are discussed. Third, the message preparation stage. Fourth, the message delivery stage. Fifth, the stage of message goal setting and the message success stage. It can be judged from the feedback.

3. The application of the three messaging techniques has been 
carried out. But Kortugi tends to one

method, namely persuasive messages with humorous appeal and one-sided issue messages.

4. Kortugi creates new knowledge opportunities about the world of dentistry and a forum for sharing views on illegal dentistry practices. Also on other education-related to dental and oral health, which are generally ignored by the community.

5. The social integration theory has been implemented by Kortugi. Kortugi has created a community that is aware of dental and oral health problems.

\section{REFERENCE}

Cangara, H. (2007). Pengantar Ilmu

Komunikasi. Jakarta: PT. Raja

Grafindo Persada.

CDC. (2019, July 9). National Center for Health Statistics. Retrieved from CDC:

https://www.cdc.gov/nchs/healthy_peo ple/hp2010/hp2010_final_review.htm \#: :text=The $\% 20$ full $\% 20$ report $\% 2 \mathrm{C} \%$ 20Healthy $\% 20$ People,life $\% 20$ and $\% 20$ eliminating $\% 20$ health $\% 20$ disparities.

Liliweri, A. (2015). Komunikasi Antar Personal. Jakarta: Prenadamedia Group.

Littlejohn, S. W., \& Foss, K. A. (2011). Theories of Human Communication. Illinois: Waveland Press.

RI, B. P. (2018). Hasil Utama Riskesdas 2018. Jakarta: Kementrian Kesehatan RI. 